\title{
Peranan Lembaga Adat Melayu Riau Dalam Penyelesaian Konflik Tanah Ulayat di Provinsi Riau
}

\author{
Maryati Bachtiar \\ Fakultas Hukum Universitas Riau \\ Jalan Pattimura No. 9, Sail, Kota Pekanbaru, Riau 28127 Indonesia
}

\begin{abstract}
Abstrak
Tujuan penelitian ini untuk menjelaskan peranan Lembaga Adat Melayu Riau (LAMR) dalam penyelesaian konflik tanah ulayat di Provinsi Riau. Jenis penelitian yang digunakan yuridis sosiologis (penelitian hukum empiris), yaitu studi empiris untuk menemukan teori mengenai proses terjadinya dan proses bekerjanya hukum dalam masyarakat. Penelitian ini termasuk ke dalam yuridis sosiologis karena langsung dilakukan di lokasi penelitian. Hasil dari penelitian ini bahwa di Provinsi Riau terdapat Lembaga Adat Melayu Riau yang dibentuk untuk mewadahi dan berfungsi melakukan pembinaan, pengembangan dan penerapan serta mengawal nilai-nilai adat Budaya Melayu. Dalam melaksanakan fungsinya, Lembaga Adat Melayu Riau juga diberikan peran untuk menyelesaikan berbagai konflik yang terjadi, termasuk sengketa tanah ulayat di Provinsi Riau yang selalu menimbulkan konflik secara terus-menerus. Kesimpulan penelitian ini dapat dijelaskan peranan Lembaga Adat Melayu Riau menyelesaikan konflik tanah ulayat di Provinsi Riau adalah mengkoordinir Lembaga Adat Melayu yang ada di tingkat kabupaten/kota serta berperan aktif memproses konflik, ikut mendampingi masyarakat dan turun langsung ke lokasi. Terdapat sejumlah hambatan yang dihadapi Lembaga Adat Melayu Riau dalam menyelesaikan konflik tanah ulayat di Provinsi Riau. Upaya yang dilakukan oleh Lembaga Adat Melayu Riau menyelesaikan konflik tanah ulayat di Provinsi Riau dengan membentuk gabungan LAMR yang ada di tingkat kabupaten/kota se-Provinsi Riau untuk melakukan mediasi yang sifatnya sementara. Karena hak-hak konstitusional yang masih kabur/tidak jelas di atas lahan yang disengketakan. LAMR juga bersifat aktif dalam mendorong penyelesaian sengketa tanah ulayat agar tidak timbul konflik.
\end{abstract}

\section{Kata Kunci: Lembaga Adat Melayu Riau, Tanah Ulayat, Konflik}

\begin{abstract}
The purpose of this study is to explain the role of Riau Malay Customary Institution (LAMR) in the settlement of ulayat land conflict in Riau Province. The type of research used in sociological jurisdiction (empirical legal research), namely empirical studies to find theories about the process of the occurrence and process of legal work in society. This research belongs to sociological juridical because it is done directly at the research location. The result of this research is that in Riau Province there is Lembaga Adat Melayu Riau which is formed to accommodate and function to do development, development and implementation as well as guarding Malay cultural values. In performing its function, the Riau Malay Customary Institution was also given a role to resolve the
\end{abstract}

\footnotetext{
"Penulis Korespondensi

E-mail: bloomengirl78@gmail.com
} 
various conflicts that occurred, including the disputes of ulayat land in Riau Province which always creates conflict continuously. The conclusion of this research can be explained the role of Riau Customary Institution of Riau to solve the ulayat land conflict in Riau Province is to coordinate the Malay Customary Institution at the district / city level and actively participate in the process of conflict, join the community and go directly to the location. There are a number of obstacles faced by Malay Customary Institution in solving the ulayat land conflict in Riau Province. The efforts made by the Riau Malay Customary Institution to resolve the ulayat land conflict in Riau Province by forming a combined LAMR at the district / city level in Riau Province to conduct temporary mediation. Due to the fuzzy constitutional rights on the disputed land. LAMR is also active in encouraging the settlement of ulayat land disputes to avoid conflicts.

\section{Keywords: Riau Malay Customary Institution, Ulayat Land, Conflict}

\section{Pendahuluan}

Tanah sebagai sumber daya alam dapat dimanfaatkan manusia untuk memenuhi kebutuhan hidup, seperti pangan, sandang dan papan (kebutuhan primer). Begitu pula bagi masyarakat hukum adat, sumber pendapatan terbesar untuk kebutuhan hidup bersumber dari pemanfaatan tanah. ${ }^{1}$ Begitu pentingnya tanah bagi kehidupan manusia maka perlu peraturan yang mengatur tentang penggunaan, peruntukan, penguasaan, dan kepemilikan tanah. $^{2}$

Pokok pengaturan sumber daya alam di Indonesia tercantum dalam Pasal 33 Ayat (3) Undang-Undang Dasar Negara Kesatuan Republik Indonesia Tahun 1945 (UUD NKRI 1945) yang mengatur "bumi, air, dan kekayaan alam yang terkandung didalamnya dikuasai oleh negara dan dipergunakan untuk sebesar-besar kemakmuran rakyat". Penjabaran Pasal 33 Ayat (3) UUD NKRI 1945 terkait tanah diatur dalam Undang-Undang Nomor 5 Tahun 1960 tentang Peraturan Dasar Pokok-pokok Agraria atau yang lebih populer dengan sebutan Undang-Undang Pokok Agraria (UUPA) yang ditetapkan pada tanggal 24 September 1960. Prinsip utama yang mendasari UUPA, yaitu bumi, air, dan ruang angkasa termasuk kekayaan alam yang terkandung didalamnya itu pada tingkat tertinggi dikuasai negara sebagai organisasi kekuasaan seluruh rakyat. ${ }^{3}$

Berkaitan tanah ulayat, UUPA mengaturnya pada Pasal 3 yang menyatakan bahwa dengan mengingat ketentuan-ketentuan pada Pasal 1 dan 2, pelaksanaan hak ulayat dan hak-hak yang serupa itu dari masyarakatmasyarakathukum adat, sepanjang menurut kenyataannya masih ada, harus sedemikian rupa sehingga sesuai dengan kepentingan nasional dan negara yang berdasarkan atas persatuan bangsa serta tidak boleh bertentangan dengan undang-undang dan peraturan-peraturan lain yang lebih tinggi.

${ }^{1}$ Budi Harsono, Hukum Agraria Indonesia: Sejarah Pembentukan Undang-Undang Pokok Agraria, Isi dan Pelaksanaannya, (Jakarta: Djambatan, 2008), hlm. 187.

${ }^{2}$ Arie Sukanti Hutagalung dkk, Kewenangan Pemerintah di Bidang Pertanahan, (Jakarta: Raja Grafindo, 2008), hlm. 27.

${ }^{3}$ Pasal 2 Ayat (1) Undang-Undang Nomor 5 Tahun 1960 tentang Peraturan Dasar Pokok-pokok Agraria 
Berdasarkan kajian sejarah, ternyata eksistensi hak adat (hak ulayat) sudah lebih dulu diakui dibandingkan dengan kemerdekaan bangsa Indonesia. Menurut Maria S.W. Sumardjono, pengakuan hak ulayat adalah wajar, karena hak ulayat beserta masyarakat hukum adat telah ada sebelum terbentuknya Negara Kesatuan Republik Indonesia tanggal 17 Agustus $1945 .^{4}$

Berdasarkan Keputusan Menteri Agraria/ Kepala Badan Pertanahan Nasional (BPN) Nomor 5 Tahun 1999 tentang Pedoman Penyelesaian Masalah Hak Ulayat Masyarakat Hukum Adat pada Pasal 2 Ayat (2) dinyatakan bahwa hak ulayat masyarakat hukum adat dianggap masih ada apabila: ${ }^{5}$

1. Terdapat sekelompok orang yang masih merasa terikat oleh tatanan hukum adatnya sebagai warga bersama suatu persekutuan hukum tertentu, yang mengakui dan menerapkan ketentuan-ketentuan persekutuan tersebut dalam kehidupannya seharihari.

2. Terdapat tanah ulayat tertentu yang menjadi lingkungan hidup para warga persekutuan hukum tersebut dan tempatnya mengambil keperluan hidupnya sehari-hari.

3. Terdapat tatanan hukum adat mengenai pengurusan, penguasaan, dan penggunaan tanah ulayat yang berlaku dan ditaati oleh para warga persekutuan hukum tersebut.

Tanah ulayat yang melekat pada mayarakat hukum adat dikelola dengan berbagai macam cara, tergantung dari musyawarah masyarakat adat setempat, karena tak jarang keberadaan dan pengolahan tanah ulayat menjadi konflik dalam masyarakat. Ketentuan hukum adat menyatakan bahwa hak ulayat tidak dapat dilepaskan, dipindahtangankan, atau diasingkan secara tetap (selamanya). Secara khusus, obyek hak menguasai negara yang dalam kenyataannya sering mengalami permasalahan adalah pelaksanaan hak menguasai negara pada tanah-tanah hak ulayat. Ketidakjelasan kedudukan dan eksistensi masyarakat hukum adat menjadi titik pangkal permasalahan sehingga keberadaan tanah ulayat tak jarang memicu terjadinya konflik di masyarakat.

Fenomena sengketa tanah muncul ke permukaan sebagian besar merupakan akibat dari pengadaan tanah untuk kepentingan pembangunan infrastruktur, industri, perumahan, pertanian, maupun perkebunan skala besar, seperti di luar Pulau Jawa, sengketa tanah sebagian besar terjadi antara masyarakat hukum adat dengan pemilik modal. Instansiinstansi pemerintah yang berkepentingan terhadap pengusahaan hutan, perkebunan, pertambangan, termasuk pertambangan minyak dan gas bumi, terutama di lokasi tanah masyarakat hukum adat, dilakukan secara tidak bijaksana sehingga menimbulkan sengketa tanah yang sampai saat ini belum terselesaikan.

Selain itu, sengketa atas tanah juga bisa terjadi karena tumpang tindihnya peraturan perundang-undangan, khususnya dalam hal ini UUPA yang awalnya merupakan payung hukum bagi kebijakan pertanahan di Indonesia menjadi tidak berfungsi dan bahkan secara substansial

${ }^{4}$ Maria S.W. Sumardjono, Kebijakan Pertanahan, (Jakarta: Kompas, 2007), hlm. 54.

${ }_{5}^{5}$ asal 2 Ayat (2) Keputusan Menteri Agraria/Kepala BPN Nomor 5 Tahun 1999 tentang Pedoman Penyelesaian Masalah Hak Ulayat Masyarakat Hukum Adat. 
terdapat pertentangan dengan diterbitkannya berbagai peraturan perundang-undangan sektoral, seperti Undang-Undang Nomor 41 Tahun 1999 tentang Kehutanan, UndangUndang Nomor 18 Tahun 2004 tentang Perkebunan, Undang-Undang Nomor 4 Tahun 2009 tentang Pertambangan Mineral dan Batubara, Undang-Undang Pengairan, UndangUndang Rumah Susun, Undang-Undang Transmigrasi, dan lain sebagainya. Keseluruhan undang-undang tersebut mempunyai posisi yang sama dan menjadikan tanah sebagai obyeknya. Benturan di lapangan tidak dapat dihindarkan antara penggunaan dan penafsiran undang-undang yang berbeda oleh pejabatpejabat pemerintahan sektoral yang berbedabeda terjadi atas konflik penguasaan tanah yang sama.

Perbedaan antara undang-undang tersebut tidak hanya dapat memberikan peluang pada perbedaan interpretasi para birokrat. Tetapi, secara substansial undang-undang tersebut tidak konsisten, banyak yang bersifat inkonsistensi, kabur, bahkan dapat menimbulkan konflik norma di antara peraturan-peraturan tersebut. Subyek dalam sengketa tersebut bisa terjadi antara pemerintah dengan masyarakat, masyarakat dengan investor, pemerintah dengan pemerintah, dan lain sebagainya.

Secara garis besar, peta permasalahan tanah dapat dikelompokkan menjadi lima sebagai berikut.

1. Masalah penggarapan rakyat atas tanah areal kehutanan, perkebunan, proyek perumahan yang ditelantar-kan, dan lain-lain.

2. Masalah yang berkenaan dengan pelanggaran ketentuan tentang landreform.

3. Akses-akses dalam penyediaan tanah untuk keperluan pembangunan.
4. Sengketa perdata berkenaaan dengan masalah tanah.

5. Masalah yang berkenaan dengan hak ulayat masyarakat hukum adat.

Lebih lanjut apabila ditinjau dari segi yuridis praktis, secara umum sengketa tanah dapat terjadi akibat kurang jelasnya bidang tanah yang dimaksudkan, batas-batas bidang tanah, luas bidang tanah, status tanah, tanah negara atau tanah hak, pemegang hak tanah, hak yang membebani tanah, pemindahan hak tanah, penunjuk lokasi dan penetapan luas tanah untuk suatu proyek pemerintah atau swasta, pelepasan/pembebasan tanah, pengosongan tanah, pemberian ganti rugi, pesangon, atau imbalan lainnya, pembatalan hak tanah, pencabutan hak tanah, pemberian hak tanah, penerbitan sertifikat tanah, serta alat-alat pembuktian adanya hak atau perbuatan hukum yang dilakukan dan sengketa-sengketa lainnya.

Interaksi sosial masyarakat pada umumnya tidak terlepas dari kepentingankepentingan, seperti kepentingan individu, keluarga dan bisnis yang dapat menimbulkan konflik (sengketa). Tentu, dibutuhkan langkah untuk memecahkan masalah serta pemahaman terhadap perilaku yang dihadapi, memahami nilai-nilai yang ada dalam masyarakat, serta memilih penyelesaian sengketa yang tepat. Penyelesaian sengketa harus dapat memberikan nilai keadilan dan kemanfaatan bagi para pihak yang bersengketa. Oleh karena itu, semestinya penyelesaian sengketa secara musyawarah merupakan jiwa bangsa Indonesia. Penyelesaian sengketa-sengketa tersebut membutuhkan penyelesaian yang sederhana, biaya murah, cepat, dan tuntas.

Ada beberapa istilah yang sering digunakan berkenaan dengan persoalan tanah. Bernhard Limbong dalam tulisannya 
menyebutkan ada tiga peristilahan, yaitu sengketa pertanahan, konflik pertanahan, dan perkara pertanahan. Disebutkan dalam ranah hukum dapat dikatakan bahwa sengketa adalah masalah antara dua orang atau lebih di mana keduanya saling mempermasalahkan suatu obyek tertentu. Hal ini terjadi karena kesalahpahaman atau perbedaan pendapat atau persepsi antara keduanya yang kemudian menimbulkan akibat hukum bagi keduanya. ${ }^{6}$ Beragamnya sengketa tanah tersebut menandakan administrasi dan pengarsipan yang dilakukan oleh pemerintah kurang bagus. Seharusnya, pemerintah semakin teliti, terperinci dan peraturan-peraturan yang berkaitan dengan status tanah harus konsisten.

Menurut Bernhard Limbong, sengketa tanah dapat berupa sengketa administratif, sengketa perdata, sengketa pidana terkait dengan pemilikan, transaksi, pendaftaran, penjaminan, pemanfaaatan, penguasaan, dan sengketa hak ulayat. ${ }^{7}$

Selain istilah 'sengketa pertanahan', dikenal pula istilah konflik pertanahan dan perkara pertanahan. Dalam Keputusan Kepala BPN Nomor 34 Tahun 2007, konflik dirumuskan sebagai perbedaan nilai, kepentingan, pendapat dan/atau persepsi antara warga atau kelompok masyarakat dan/atau warga atau kelompok masyarakat dengan badan hukum (privat dan publik), masyarakat dengan masyarakat mengenai status penguasaan dan/ atau status kepemilikan dan/atau status penggunaaan atau pemanfaatan atas bidang tanah tertentu oleh pihak tertentu, atau status
Keputusan Tata Usaha Negara menyangkut penguasaan, pemilikan, dan penggunaan atau pemanfaatan atas bidang tanah tertentu serta mengandung aspek politik, ekonomi, dan sosial budaya. ${ }^{8}$

Marni Emmy Mustafa mengemukakan pendapat bahwa penyelesaian sengketa pertanahan melalui pengadilan dirasakan tidak memuaskan. Tidak sedikit mereka yang telah menduduki tanah selama bertahun-tahun ditolak gugatannya untuk mempertahankan hak karena adanya pihak lain yang menguasai tanah yang bersangkutan. Desakan untuk membentuk pengadilan khusus pertanahan sudah lama diwacanakan. Namun, pembentukan suatu sistem peradilan baru tersebut merupakan pekerjaan raksasa. Hal itu dimulai dari perubahan paradigma, penyiapan doktrin dan asas, komponen-komponen sistem peradilan, sampai ke pengaturan baru dalam beracara, penataan organisasi, serta anggaran dan sumber daya manusia. Dengan kondisi obyektif tersebut, saat inilah untuk memikirkan kembali, merencanakan ulang, serta merestrukturisasi sarana dan prasarana hukum, agar hak-hak yuridis mendapat perlindungan dan penegakan hukum yang sama di bidang pertanahan. Dalam bidang penyelenggaraan hukum dan undang-undang, pembentukan pengadilan khusus tanah adalah yang paling penting untuk mencapai tujuan ini. ${ }^{9}$

Pengadilan pertanahan sebagaimana dikemukakan di atas perlu dikaji dan dipikirkan bersama sebagai salah satu bentuk alternatif penanggulangan sengketa pertanahan.

${ }^{6}$ Bernhard Limbong, Konflik Pertanahan, (Jakarta: Pustaka Margaretha, 2012), hlm. 48.

${ }^{7}$ Ibid, hlm. 49.

${ }^{8}$ Kartika Sandra dan Candra Gautama, Menggugat Posisi Masyarakat Adat terhadap Negara, (Jakarta: Sekretariat Aliansi Masyarakat Adat Nusantara, 1999), hlm. 40.

9Marni Emmy Mustafa, Pengadilan Pertanahan Untuk Menunjang Percepatan Penyelesaian Sengketa, Konflik di Prahara Pertanahan, Jurnal Varia Peradilan, Tahun XXVI, Nomor 333, Agustus 2013, hlm. 38. 
Alternatif lain dengan lebih memfungsikan lembaga-lembaga peradilan adat, seperti Lembaga Kedamangan di Kalimantan Tengah yang lebih memahami tentang persoalanpersoalan tanah adat yang timbul menjadi sengketa.

Provinsi Riau merupakan Provinsi ke-3 terbanyak perusahaan pemegang $\mathrm{HPH}$ (Hak Penebangan Hutan) (67 buah) dengan luas areal kerja 5.587.860 Hektar $(\mathrm{Ha})$ yang berupa kawasan HPH, Hutan Produksi (HP), dan Hutan Produksi Konversi (HPK). Sampai Maret 1993, dari jumlah HPH sebanyak itu, sebagian yang membangun Hutan Tanaman Industri (HTI) Pulp (985.000 Ha) merupakan ke-2 terluas setelah Provinsi Kalimantan Timur. Belum lagi beroperasinya perusahaan besar yang teleh mengantongi izin Hak Guna Usaha (HGU) untuk perkebunan kelapa sawit atau izin untuk pertambangan gas dan minyak bumi. Di sisi lain, hak-hak masyarakat adat dalam penguasaan lahan semakin terpinggirkan, baik hak sipil dan politik maupun hak ekonomi dan sosial budaya, terutama sekali tanah/hutan ulayat yang kini mempunyai potensi konflik yang sangat besar dengan pihak ketiga, karena selama ini terlihat tanah adat dan hutan ulayat sudah banyak berpindah tangan kepada pihak ketiga karena kesalahan yang dibuat oleh pemerintah maupun oknum dari pemangku adat yang bekerja sama untuk kepentingan pribadi guna mendapatkan keuntungan tanpa melihat sejarah tanah adat hutan ulayat tersebut.

Pemerintah daerah harus dapat menyerap aspirasi yang berkembang di masyarakat adat tentang tanah ulayat dan menyikapinya dengan menghimpun semua potensi yang ada, seperti Lembaga Adat Melayu, baik tingkat kabupaten/kota maupun tingkat Provinsi Riau. Berbagai kasus dapat dilihat terdesaknya hak masyarakat hukum adat seiring dengan derasnya investasi maupun proyek pembangunan pemerintah sejak tahun 1970-an telah mendorong pemikiran untuk menentukan kriteria obyektif tentang keberadaan hak ulayat, baik subyek, obyek, dan kewenangannya.

Dari sisi lain, apabila masyarakat adat mampu mengelola hutan tanah ulayat, menebang hutannya dan tanahnya dijadikan perkebunan kelapa sawit atau komoditi lainnya yang sesuai dengan rencana tata ruang, tetapi kesempatan ini tidak pernah ditawarkan atau diberikan, karena pemerintah melalui instansi terkait telah terlebih dahulu mengeluarkan $\mathrm{HPH}$ selanjutnya HGU kepada pihak lain. Kalau masyarakat ulayat yang melakukan pengelolaan hutan tanah ulayat demi untuk kesejahteraan dan kemakmuran masyarakat adat beserta keturunannya dan menghapus kemiskinan dan kemelaratan masyarakat adat Melayu Riau, bukankah itu juga sama artinya demi untuk kepentingan nasional dan negara, karena masyarakat adat yang ada di Riau merupakan masyarakat Indonesia.

Menurut tokoh Lembaga Adat Melayu Riau, penyelesaian yang pernah diambil secara jalur hukum selalu bersifat kasuistis dan sporadis tidak pernah sampai kepada akar permasalahan. Ambil saja contoh kasus 'Sinama Nenek' antara PT Perkebunan Nusantara V (PTPN V) dengan MasyarakatAdat Sinama Nenek, di mana PTPN $V$ telah mengambil tanah ulayat lebih kurang $2.800 \mathrm{Ha}$, yang tidak masuk dalam kawasan yang diberi konsesi HGU. Berdasarkan Surat Keputusan Gubernur Riau Nomor Kpts.131/N/1983 tanggal 3 Mei 1983, kepada PTPN V diberikan pencadangan lahan untuk perkebunan seluas $30.000 \mathrm{Ha}$, yang terdiri dari $13.000 \mathrm{Ha}$ berada di Kecamatan Tandun (sekarang berada di 
wilayah Pemerintah Kabupaten Rokan Hulu) dan $17.000 \mathrm{Ha}$ berada di Kenegerian Sama Nenek Kecamatan Siak Hulu (sekarang Kenegerian Sinama Nenek Kecamatan Tapung Hulu Kabupaten Kampar). Dari lahan seluas 17.000 Ha yang telah mendapatkan HGU seluas $14.200 \mathrm{Ha}$, sedangkan sisanya $2.800 \mathrm{Ha}$ berdasarkan Surat Kantor Wilayah (Kanwil) Pertanahaan Propinsi Provinsi Riau Nomor 500/ 1114/BPN, tanggal 11 November 2000 dienclave untuk masyarakat tempatan melalui pola kemitraan, karena lahan tersebut merupakan bekas peladangan masyarakat yang telah dikelola masyarakat Sinama Nenek sejak tahun 1981. Sampai saat ini, PTPN V tidak mau menyerahkan 2.800 Ha tersebut, sehingga masyarakat tetap menutut hak mereka sampai dipenuhi. Dari kasus tersebut terlihat dihadapan hukum masyarakat Sinama Nenek berada pada jalur yang benar, tetapi tetap saja tidak dapat menikmati keadilan hukum. ${ }^{10}$

Beberapa kasus penyelesaian sengketa hutan tanah ulayat dengan pihak perusahaan menggambarkan telah terjadinya penyalahgunaan wewenang, manipulasi dan hal-hal yang justru bertentangan dengan hukum, hukum adat, dan rasa keadilan.

Provinsi Riau terdapat lembaga adat yang belum diberikan peran untuk menyelesaikan berbagai konflik yang terjadi. Pada dasarnya yang disebut dengan penyelesaian konflik agraria bukan hanya pembuktian hukum formal dari tanah yang dikonflikkan, melainkan pemenuhan rasa keadilan pada korban konflik agraria. Selama ini, pihak rakyatlah yang selalu jadi korban konflik agraria.

Berdasarkan uraian di atas penulis tertarik untuk melakukan penelitian tentang peranan Lembaga Adat Melayu Riau (LAMR) dalam penyelesaian konflik tanah ulayat di Provinsi Riau. Penelitian ini penting karena belum pernah diteliti sebelumnya. Penelitian terdahulu belum menyentuh isu yang sama, meskipun beberapa penelitian terdahulu menyinggung seputar tanah ulayat. Tetapi, isu yang dibahas tidak terkait penyelesaian konflik tanah ulayat.

Mohd. Yunus pernah meneliti tentang konflik pertanahan dan penyelesaiannya menurut adat di Provinsi Riau. Dalam penelitiannya menjelaskan penyelesaian konflik yang terjadi menurut tokoh-tokoh lembaga adat Melayu Riau harus dilakukan dengan prinsip berwawasan nasional artinya keputusan yang diambil justru diharapkan menjadi perekat kebersamaan, kesetiakawanan, solidaritas sesama anak bangsa. Penyelesaian haruslah yang adil dan beradab berdaya guna dan berhasil guna untuk kesejahteraan masyarakat. ${ }^{11}$

Adli Hirzan meneliti tentang gerakan masyarakat dalam membentuk kenegerian tiga lorong baturijal hulu sebagai desa adat di Kecamatan Peranap Kabupaten Indragiri Hulu tahun 2014-2015. ${ }^{12}$ Annisa Sundari Ningsih pernah meneliti tentang mediasi dalam penyelesaian sengketa tanah ulayat oleh ninikmamak Desa Pulau Jambu Kecamatan Kuok Kabupaten Kampar Provinsi Riau. Dalam 2013.

${ }^{10}$ Wawancara dengan tokoh Lembaga Adat Melayu Riau Ahmad Bebas di Pekanbaru tanggal 24 Oktober

${ }^{11}$ Mohd. Yunus, Konflik Pertanahan dan Penyelesaiannya Menurut Adat di Provinsi Riau, Jurnal Menara, Volume 12, Nomor 1, Januari-Juni 2013, hIm. 38.

${ }^{12}$ Adli Hirzan, Gerakan Masyarakat Dalam Membentuk Kenegerian Tiga Lorong Baturijal Hulu Sebagai Desa Adat di Kecamatan Peranap Kabupaten Indragiri Hulu Tahun 2014-2015, Jurnal JOM FISIP, Volume 4, Nomor 2, Oktober 2017, hlm. 13. 
penelitian dijelaskan proses mediasi dalam penyelesaian sengketa tanah ulayat oleh NinikMamak Desa Pulau Jambu sudah dijalankan dengan baik. Namun, belum efektif karena mediasi dapat dilakukan jika masalah yang terjadi melibatkan kelompok internal saja. Tetapi, jika melibatkan pihak luar Ninik-Mamak tidak bisa menyelesaikan masalah dengan mediasi. ${ }^{13}$

Shrimanti Indira Pratiwi meneliti tentang penyelesaian sengketa tanah ulayat antara masyarakat hukum adat dengan Taman Nasional Tessonilo. Penelitiannya menjelaskan penyebab terjadinya sengketa antara masyarakat hukum adat dan Taman Nasional Tesso Nilo di Desa Air Hitam Kecamatan Ukui Kabupaten Pelalawan bermula ketika tahun 2004 pemerintah menetapkan kawasan hutan Tesso Nillo sebagai Taman Nasional Tesso Nillo. Padahal, di dalam kawasan hutan tersebut masyarakat Adat Petalangan batin putih mengantungkan hidup dan kehidupannya. ${ }^{14}$

Pusat Penelitian dan Pengembangan Sistem Hukum Nasional Badan Pembinaan Hukum Nasional Kementerian Hukum dan Hak Asasi Manusia RI 2013 pernah meneliti tentang peran masyarakat hukum adat dalam penanggulangan pembalakan liar. Penelitian ini menjelaskan praktik pelaksanaan dan penegakan hukum, di lokasi penelitian, Kabupaten Kampar Provinsi Riau dan Kabupaten Nunukan, Provinsi Kalimantan Timur, meskipun hutan adat telah diakui dan diatur dalam masing-masing dengan Peraturan Daerah (Perda). Namun, pelaksanaan dan penegakan peraturan tersebut, di satu sisi masih dihadapkan pada disharmonisasi antara penerapan nilai-nilai hukum praksis dengan nilai hukum yang lebih tinggi, yakni nilai-nilai hukum instrumental dan nilai-nilai hukum dasar. Selain itu, pelaksanaan Perda di dua lokasi penelitian (Kampar, Riau dan Nunukan Kalimantan Timur), belum didukung oleh tersedianya data (inpentarisasi dan registrasi) hutan dan hutan adat yang ada, di masing-masing lokasi penelitian. Akibatnya, aturan hukum yang ada belum dapat menggerakkan pengeloloaan hutan ke tujuan lebih adil, bermanfaat dan berkesinambungan. ${ }^{15}$

Menelaah penelitian terdahulu di atas jelaslah tidak membahas peranan LAMR dalam penyelesaian konflik tanah ulayat di Provinsi Riau. Oleh karena itu, penelitian ini merupakan sesuatu yang baru atau berbeda dengan penelitian terdahulu (novelty). Dengan demikian, penelitian ini penting dilaksanakan karena akan memberikan konstribusi yang berarti bagi ilmu pengetahuan. Adapun permasalahan yang dibahas dalam penelitian ini, yaitu Pertama, bagaimanakah peranan Lembaga Adat Melayu Riau (LAMR) dalam penyelesaian konflik tanah ulayat di Provinsi Riau? Kedua, apa sajakah hambatan-hambatan Lembaga Adat Melayu Riau (LAMR) dalam penyelesaian konflik tanah ulayat di Provinsi Riau? Hasil yang diharapkan dari penelitian ini,

${ }^{13}$ Annisa Sundari Ningsih, Mediasi Dalam Penyelesaian Sengketa Tanah Ulayat Oleh Ninik-Mamak Desa Pulau Jambu Kecamatan Kuok Kabupaten Kampar Provinsi Riau, Skripsi, Jurusan Ilmu Pemerintahan Fakultas IImu Sosial dan Ilmu Politik Universitas Riau, 2015, hlm. 12.

${ }^{14}$ Shrimanti Indira Pratiwi, Penyelesaian Sengketa Tanah Ulayat Antara Masyarakat Hukum Adat Dengan Taman Nasional Tessonilo, Program Magister Kenotariatan, Fakultas Hukum Universitas Brawijaya, 2014, hlm. 20.

${ }^{15}$ Tim Penelitian Hukum, Peran Masyarakat Hukum Adat Dalam Penanggulangan Pembalakan Liar, Pusat Penelitian dan Pengembangan Sistem Hukum Nasional Badan Pembinaan Hukum Nasional Kementerian Hukum dan Hak Asasi Manusia RI, 2013, hIm. 102-103. 
yaitu menjelaskan peranan Lembaga Adat Melayu Riau (LAMR) dalam penyelesaian konflik tanah ulayat di Provinsi Riau. Selain itu, penelitian ini diharapkan dapat dijadikan pengembangan ilmu pengetahuan khususnya ilmu hukum.

\section{Metode Penelitian}

Jenis penelitian yang digunakan yuridis sosiologis (penelitian hukum empiris), yaitu studi empiris untuk menemukan teori mengenai proses terjadinya dan proses bekerjanya hukum dalam masyarakat. ${ }^{16}$ Penelitian ini termasuk ke dalam yuridis sosiologis karena langsung dilakukan di lokasi penelitian. Sifat penelitian ini deskriptif, artinya penelitian ini memberikan gambaran tentang kenyataan yang ada secara lengkap dan jelas mengenai peranan Lembaga Adat Melayu Riau dalam penyelesaian konflik tanah ulayat di Provinsi Riau. Sumber data yang digunakan data primer, yaitu data yang diperoleh langsung dari sumber utama/ responden atau dari hasil observasi sendiri. Selain itu, didukung dengan data sekunder yang diperoleh dari bahan perpustakaan berupa peraturan perundang-undangan, buku-buku, literatur dan serta pendapat para ahli yang relevan dengan penelitian ini.

Teknik pengumpulan data primer dilakukan dengan cara wawancara, yaitu melakukan tanya jawab langsung dengan responden, dalam hal ini dengan Ketua Dewan Pengurus Harian Lembaga Adat Melayu Riau. Teknik pengumpulan data sekunder dilakukan dengan melakukan kajian kepustakaan yang berkaitan dengan penelitian ini. Data yang telah dikumpulkan, dikelompokkan dan diklasifikasi- kan sesuai permasalahan yang dibahas. Kemudian data tersebut disajikan dalam bentuk kalimat yang dapat dimengerti dan dipahami. Selanjutnya, penulis melakukan analisis secara kualitatif, yaitu analisis data tidak menggunakan angka-angka, tetapi menghubungkan antara data dengan teori dan pendapat para ahli yang relevan untuk memperoleh kesimpulan penelitian ini.

\section{Pembahasan}

Peranan Lembaga Adat Melayu Riau (LAMR) Dalam Penyelesaian Konflik Tanah Ulayat di Provinsi Riau

Lembaga Adat Melayu Riau adalah lembaga yang dibentuk untuk mewadahi dan berfungsi melakukan pembinaan, pengembangan, dan penerapan serta mengawal nilainilai adat Budaya Melayu. Banyaknya kasus tanah di Provinsi Riau yang berkepanjangan menyita perhatian di Provinsi Riau, termasuk Lembaga Adat Melayu Riau. Berdasarkan hasil wawancara mengenai peranan Lembaga Adat Melayu Riau dalam penyelesaian konflik tanah ulayat di Provinsi Riau diketahui bahwa Lembaga Adat Melayu Riau berperan mengkoordinir Lembaga Adat Melayu yang ada di tingkat kabupaten/kota untuk dapat menangani masalah tanah ulayat yang melibatkan masyarakat adat, instansi pemerintah, maupun perusahaan-perusahaan. Lembaga Adat Melayu Riau juga mendukung penyelesaian hukum terhadap kasus-kasus tanah ulayat yang ada di Provinsi Riau, baik yang menimbulkan sengketa maupun konflik. ${ }^{17}$

Tanah ulayat di dalam adat Melayu terbagi menjadi tiga bentuk, yaitu sebagai berikut. ${ }^{18}$

\footnotetext{
${ }^{16}$ Bambang Sunggono, Metode Penelitian Hukum, (Jakarta: PT Raja Grafindo Persada, 2001), hlm. 43.

${ }^{17}$ Wawancara dengan Al Azhar selaku Ketua Dewan Pengurus Harian Lembaga Adat Melayu Riau di Pekanbaru tanggal 9 Oktober 2015.

${ }^{18} \mathrm{Ibid}$.
} 
1. Tanah kayat/tersurat, yaitu tanah yang dikuasai oleh sultan dan raja yang betapak di wilayah Riau.

2. Tanah ulayat yang ditempati oleh suku setempat, dikuasakan kepada ninik mamak, datuk-datuk milik masyarakat komunal adat.

3. Tanah hayat/tumbuh, seperti tanah tumpukan pasir yang membentuk sebuah pulau, seperti di Kampar ada Pulau Godang.

Dalam menyelesaikan konflik tanah ulayat di Provinsi Riau, Lembaga Adat Melayu Riau juga berperan memproses konflik ini secara aktif dengan ikut mendampingi dan turun langsung ke lokasi konflik tanah ulayat tersebut. Namun, Lembaga Adat Melayu Riau dalam menyelesaikan kasus ini tidak mudah dan tidak cepat karena tidak semua pemilik tanah adat yang mengetahui masalah hukum, seperti mereka tidak mengetahui dan tidak memiliki surat tanda bukti keaslian kepemilikan tanah, sehingga Lembaga Adat Melayu Riau harus mengikuti aturan yang telah ditetapkan oleh negara. Lembaga Adat Melayu Riau tidak dapat menyelesaikan konflik jika status kepemilikan tanah masih belum jelas. ${ }^{19}$

Berdasarkan hasil wawancara diketahui bahwa data jumlah konflik tanah yang terjadi di Provinsi Riau dalam seminggu ada lebih kurang tiga kasus, sehingga dalam kurun waktu dua tahun terakhir ada sekitar 260 titik konflik mengenai tanah. Dari 260 titik konflik tersebut, ada sekitar 170 titik konflik mengenai tanah ulayat. Dari 170 titik konflik tanah ulayat tersebut, hanya lima kasus tanah ulayat yang menjadi reda dan tidak terjadi konflik karena berhasil dibuktikan dengan mengukur peta batas tanah sengketa. ${ }^{20}$

Konflik tanah ulayat yang berhasil diredakan adalah konflik Teluk Meranti dengan Teluk Binjai, konflik yang melibatkan PT PAPP, konflik yang melibatkan PT SSL, konflik yang melibatkan masyarakat Bangun Purba di Rokan Hulu, dan konflik yang melibatkan anak perusahaan Surya Dumai Group. ${ }^{21}$

\section{Hambatan-hambatan Lembaga Adat Melayu Riau (LAMR) Dalam Penyelesaian Konflik Tanah Ulayat di Provinsi Riau}

Sengketa pertanahan adalah proses interaksi antara dua orang atau lebih atau sekelompok yang masing-masing memperjuangkan kepentingannya atau obyek yang sama, yaitu tanah dan benda-benda lain yang berkaitan dengan tanah, seperti air, tanaman, tambang, juga udara yang berada di atas tanah yang bersangkutan.

Menurut Maria S.W. Sumardjono, secara garis besar permasalahan tanah dapat dikelompokkan menjadi lima sebagai berikut. ${ }^{22}$

1. Masalah penggarapan rakyat atas tanah areal perkebunan, kehutanan, proyek perumahan yang terlantarkan dan lain-lain.

2. Masalah yang berkenaan dengan pelanggaran ketentuan kepemilikan dan penguasaan tanah serta hubungan hukum yang bersangkutan dengan tanah (landreform).

${ }^{22}$ Maria S.W.Sumardjono, Puspita Serangkum Masalah Hukum Agraria, (Yogyakarta: Penerbit Liberty, 2001), hlm. 28. 
3. Akses-akses penyediaan tanah untuk keperluan pembangunan.

4. Sengketa perdata yang berkenaan dengan tanah.

5. Masalah yang berkenaan dengan hak ulayat masyarakat hukum adat.

Menurut Suyud Margono, sengketa yang sering terjadi saat ini sebagai berikut.

1. Sengketa tradisional tentang warisan, keluarga, dan tanah.

2. Sengketa bisnis yang serta berat dengan unsur keuangan, perbankan, peraturan perundang-undangan, etika, dan sebagainya.

3. Sengketa lingkungan yang rumit dengan masalah pembuktian ilmiah.

4. Sengketa tenaga kerja yang diwarnai dengan masalah hak asasi, reputasi negara, dan perhatian masyarakat tradisional. ${ }^{23}$

Secara yuridis, di dalam buku karangan Arie Sukanti Hutagalung, Boedi Hasono lebih lanjut memperinci masalah tanah yang dapat disengketakan sebagai berikut.

1. Sengketa mengenai bidang tanah yang dimaksud.

2. Sengketa mengenai batas-batas bidang tanah.

3. Sengketa mengenai luas bidang tanah.

4. Sengketa mengenai status tanah, tanah negara atau tanah hak.

5. Sengketa mengenai pemegang hak tanah.

6. Sengketa mengenai hak tanah yang membebaninya.

7. Sengketa mengenai pemindahan hak tanah.
8. Sengketa mengenai penunjuk lokasi dan penetapannya untuk suatu proyek pemerintah atau swasta.

9. Sengketa mengenai pelepasan/ pembebasan tanah.

10. Sengketa mengenai pengosongan tanah.

11. Sengketa mengenai pemberian ganti kerugian.

12. Sengketa mengenai pembatalan hak tanah.

13. Sengketa mengenai pemberian hak tanah.

14. Sengketa mengenai pencabutan hak tanah.

15. Sengketa mengenai pemberian sartifikat tanah.

16. Sengketa mengenai alat-alat pembuktian adanya hak/perbuatan hukum yang dilakukan dengan sengketasengketa lainnya. ${ }^{24}$

Dalam penyelesaian konflik tanah ulayat di Provinsi Riau, terkadang akan timbul hambatan dalam penanganannya. Hambatanhambatan yang timbul bisa datang dari para pihak yang bersengketa maupun dari pihak yang ikut terlibat dalam menangani penyelesaian sengketa/konflik tanah di Provinsi Riau, salah satunya, yaitu Lembaga Adat Melayu Riau.

Berdasarkan hasil wawancara yang dilakukan penulis, diketahui ada beberapa hambatan Lembaga Adat Melayu Riau dalam penyelesaian konflik tanah ulayat di Provinsi Riau, yaitu

1. Pemerintah Provinsi Riau tidak serius menangani konflik tanah ulayat. Dalam

${ }^{23}$ Suyud Margono, ADR (Alternatif Dispute Resolution) dan Arbitrase: Proses Perkembangan dan Aspek Hukum, (Jakarta: Ghalia Indonesia, 2000), hlm. 188-189.

${ }^{24}$ Arie Sukanti Hutagalung, Penyelesaian Sengketa Tanah Menurut Hukum yang Berlaku, Jurnal Hukum Bisnis, 2002, hlm. 52. 
hal ini, pemerintah belum mengakui eksistensi hak-hak tradisional dalam memenuhi hak masyarakat adat.

2. Sulitnya untuk menentukan tanah tersebut merupakan tanah ulayat, karena dari fisik sudah ada mengalami perubahan mengenai batas-batas atau patok yang sudah hilang, sehingga masyarakat adat tidak memiliki bukti yang kuat mengenai kepemilikan yang sah dari tanah ulayat tersebut. ${ }^{25}$

Berdasarkan hasil wawancara yang penulis lakukan, diketahui bahwa tanah adat Melayu di Provinsi Riau dimiliki oleh masyarakat pendatang, karena mereka datang dari perairan sungai di Riau. Masyarakat pendatang ini menempati daerah baru yang ditemui ketika datang ke Riau. Hal inilah yang menyebabkan akar terjadinya konflik kepemilikan tanah adat/ulayat yang tidak bisa dibuktikan kepemilikan-nya, karena tidak dapat membuktikan asal-usul nenek moyang mendapatkan tanah ulayat tersebut. Dari mana nenek moyangnya berasal, sementara data yang dibutuhkan sudah berumur ratusan tahun. ${ }^{26}$

Faktor-faktor penyebab terjadinya konflik tanah ulayat di Provinsi Riau terkait batas-batas yang tidak jelas, tidak adanya surat bukti kesepakatan dan perjanjian yang pernah dibuat oleh nenek moyang dari kedua belah pihak, meningkatnya nilai-nilai tanah secara ekonomi, serta melunturnya nilai budaya dan hukum adat. $^{27}$
Upaya yang Dilakukan oleh Lembaga Adat Melayu Riau (LAMR) Dalam Penyelesaian Konflik Tanah Ulayat di Provinsi Riau

Dalam menangani banyaknya kasus tanah ulayat di Provinsi Riau, Lembaga Adat Melayu Riau membentuk gabungan Lembaga Adat Melayu yang ada di tingkat kota dan kabupaten untuk melakukan mediasi yang sifatnya sementara. Karena hak-hak konstitusional masih kabur/tidak jelas di atas lahan yang disengketakan tersebut. Lembaga Adat Melayu Riau bersifat aktif mendorong penyelesaian sengketa tanah ulayat agar tidak timbul konflik. ${ }^{28}$

Bentuk penyelesaian sengketa merupakan serangkaian aktivitas para pihak yang bersengketa menggunakan strategi penyelesaiannya. Mekanisme penyelesaian sengketa dapat muncul dalam berbagai bentuk. Secara umum, media penyelesaian sengketa yang tersedia dapat digolongkan dalam dua bentuk, yaitu melalui pengadilan dan penyelesaian sengketa di luar pengadilan atau sering disebut sebagai alternatif penyelesaian sengketa.

Alternatif penyelesaian sengketa merupakan sebuah pengertian konsep penyelesaian konflik atau sengketa kooperatif diarahkan pada solusi konflik atau sengketa yang bersifat win-win solution (menang). Caracara untuk menyelesaikan sengketanya sebagai berikut.

1. Memberikan saja

Dalam tahap ini, masyarakat yang merasa diperlakukan tidak adil atau dirugikan gagal dalam upaya

\footnotetext{
${ }^{25}$ Wawancara dengan Al Azhar selaku Ketua Dewan Pengurus Harian Lembaga Adat Melayu Riau di Pekanbaru tanggal 9 Oktober 2015.

${ }^{26}$ Ibid.

${ }^{27}$ Ibid.

${ }^{28}$ lbid.
} 
menegakkan tuntutannya, sehingga mereka mengabaikan saja isu yang menimbulkan tuntutannya dan tetap berhubungan dengan pihak yang dirasakan merugikannya. Hal ini dilakukan karena berbagai kemungkinan, seperti kekurangan informasi proses pengajuan keluhan ke pengadilan, kurangnya akses ke lembaga pengadilan atau sengaja tidak diproses ke pengadilan karena diperkirakan kerugian lebih besar dari pada keuntungan (baik materi maupun kejiwaannya).

2. Mengelak

Pada tahap ini, pihak yang merasa dirugikan memilih untuk mengurangi hubungan-hubungan dengan pihak yang merugikannya atau sama sekali tidak berhubungan. Misalnya, dalam hubungan bisnis hal semacam ini dapat terjadi. Dengan mengela maka isu yang menimbulkan keluhan dielakkan saja.

3. Paksaan

Tahap selanjutnya, yaitu paksaan salah satu pihak memaksa pemecahan kepada pihak lain. Tindakan yang bersifat memaksa ini atau ancaman untuk menggunakan kekerasan pada umumnya mengurangi kemungkinan penyelesaian secara damai.

4. Perundingan

Pada tahapan perundingan, dua pihak yang berhadapan merupakan para pengambil keputusan pemecahan dari permasalahan yang mereka hadapi dilakukan oleh kedua belah pihak. Mereka sepakat tanpa adanya pihak ketiga yang ikut campur. Kedua belah pihak berupaya untuk saling meyakinkan dengan menggunakan aturan yang mereka buat sendiri.

5. Mediasi

Dalam cara ini, ada pihak ketiga yang membantu kedua belah pihak yang berselisih untuk menemukan kesepakatan. Pihak ketiga ini dapat ditentukan oleh kedua belah pihak atau ditunjuk oleh orang yang mempunyai wewenang.

6. Arbitrase

Kedua belah pihak sepakat untuk meminta bantuan perantara pihak ketiga, yaitu arbiter. Sejak semula telah setuju bahwa mereka akan menerima apapun keputusan yang diambil oleh arbiter tersebut.

7. Pengadilan.

Pihak ketiga berhak mencampuri pemecahan masalah, lepas dari keinginan pihak sengketa. Pihak ketiga juga memiliki hak membuat dan menegakkan keputusan itu, yang artinya bahwa keputusan diupayakan untuk dilaksanakan.

Negosiasi merupakan bentuk penyelesaian sengketa lainnya yang dilakukan oleh pihak-pihak yang bersengketa. Penyelesaian sengketa model ini untuk menghasilkan suatu keputusan atau kesepakatan tanpa campur tangan pihak ketiga. Biasanya model ini tidak berdasarkan peraturan yang ada, melainkan aturan yang mereka buat sendiri.

Penyelesaian yang melibatkan pihak ketiga meliputi penyelesaian yang berbentuk ajudikasi, arbitrase dan mediasi. Bentukbentuk penyelesaian sengketa ini mempunyai persamaan dan perbedaan. Persamaannya, ketiga bentuk penyelesaian bersifat triadic karena melibatkan pihak ketiga. Perbedaannya ajudikasi merupakan penyele- 
saian yang dilakukan oleh pihak ketiga yang berwenang untuk campur tangan dan dapat melaksanakan keputusan yang ditentukan tanpa memperhatikan kehendak kedua belah pihak. Berbeda dengan ajudikasi, arbitrase merupakan penyelesaian sengketa yang dilakukan oleh pihak ketiga dan keputusannya disetujui oleh pihak-pihak yang bersengketa, sedangkan mediasi penyele-saian melibatkan pihak ketiga untuk membantu mencapai persetujuan.

\section{Kesimpulan}

1. Peranan Lembaga Adat Melayu Riau (LAMR) menyelesaikan konflik tanah ulayat di Provinsi Riau adalah mengkoordinir Lembaga Adat Melayu yang ada di tingkat kabupaten/kota serta berperan aktif memproses konflik, ikut mendampingi masyarakat dan turun langsung ke lokasi.

2. Hambatan-hambatan Lembaga Adat Melayu Riau (LAMR) menyelesaikan konflik tanah ulayat di Provinsi Riau sebagai berikut.

a. Pemerintah Provinsi Riau tidak serius dalam menangani konflik tanah ulayat karena pemerintah belum mengakui eksistensi hak-hak tradisional dalam memenuhi hak masyarakat adat.

b. Sulitnya menentukan tanah ulayat karena secara fisik telah mengalami perubahan mengenai batas-batas atau patok yang sudah hilang, sehingga masyarakat adat tidak memiliki bukti yang kuat mengenai kepemilikan yang sah dari tanah ulayat tersebut.

3. Upaya yang dilakukan oleh Lembaga Adat Melayu Riau (LAMR) menyelesaikan konflik tanah ulayat di Provinsi Riau dengan membentuk gabungan LAMR yang ada di tingkat kabupaten/kota se-Provinsi Riau untuk melakukan mediasi yang sifatnya sementara. Karena hak-hak konstitusional yang masih kabur/tidak jelas di atas lahan yang disengketakan. LAMR juga bersifat aktif dalam mendorong penyelesaian sengketa tanah ulayat agar tidak timbul konflik.

\section{Saran}

1. Lembaga Adat Melayu Riau (LAMR) sebagai lembaga yang dibentuk untuk mewadahi dan berfungsi melakukan pembinaan, pengembangan dan penerapan serta mengawal nilai-nilai adat Budaya Melayu harus bisa berperan aktif dalam penyelesaian konflik tanah ulayat di Provinsi Riau.

2. Pemerintah Provinsi Riau harus lebih serius dalam menangani sengketa tanah ulayat di Provinsi Riau agar kedepannya tidak menimbulkan konflik yang melibatkan banyak pihak.

3. Pemerintah Provinsi Riau sebaiknya membuat Perda tentang tanah-tanah ulayat di wilayah Provinsi Riau, sehingga jelas aturan tentang eksistensi tanah-tanah ulayat di Provinsi Riau.

\section{Referensi}

Adli Hirzan. Gerakan Masyarakat Dalam Membentuk Kenegerian Tiga Lorong Baturijal Hulu Sebagai Desa Adat di Kecamatan Peranap Kabupaten Indragiri Hulu Tahun 2014-2015. Jurnal JOM FISIP. Volume 4. Nomor 2. Oktober 2017.

Annisa Sundari Ningsih. Mediasi Dalam Penyelesaian Sengketa Tanah Ulayat Oleh Ninik-Mamak Desa Pulau Jambu Kecamatan Kuok Kabupaten Kampar Provinsi Riau. Skripsi. Jurusan IImu 
Pemerintahan Fakultas IImu Sosial dan IImu Politik Universitas Riau. 2015.

Arie Sukanti Hutagalung dkk. 2008. Kewenangan Pemerintah di Bidang Pertanahan. Jakarta: Raja Grafindo.

Arie Sukanti Hutagalung. Penyelesaian Sengketa Tanah Menurut Hukum yang Berlaku. Jurnal Hukum Bisnis. 2002.

Bambang Sunggono. 2001. Metode Penelitian Hukum. Jakarta: PT Raja Grafindo Persada.

Bernhard Limbong. 2012. Konflik Pertanahan. Jakarta: Pustaka Margaretha.

Budi Harsono. 2008. Hukum Agraria Indonesia:

Sejarah Pembentukan Undang-Undang Pokok Agraria, Isi dan Pelaksanaannya. Jakarta: Djambatan.

Kartika Sandra dan Candra Gautama. 1999. Menggugat Posisi Masyarakat Adat terhadap Negara. Jakarta: Sekretariat Aliansi Masyarakat Adat Nusantara.

Maria S.W.Sumardjono. 2001. Puspita Serangkum Masalah Hukum Agraria. Yogyakarta: Penerbit Liberty. 2007. Kebijakan

Pertanahan. Jakarta: Kompas.
Marni Emmy Mustafa. Pengadilan Pertanahan Untuk Menunjang Percepatan Penyelesaian Sengketa, Konflik di Prahara Pertanahan. Jurnal Varia Peradilan. Tahun XXVI. Nomor 333. Agustus 201.

Mohd. Yunus. Konflik Pertanahan dan Penyelesaiannya Menurut Adat di Provinsi Riau. Jurnal Menara. Volume 12. Nomor 1. Januari-Juni 2013.

Shrimanti Indira Pratiwi. Penyelesaian Sengketa Tanah Ulayat Antara Masyarakat Hukum Adat Dengan Taman Nasional Tessonilo. Program Magister Kenotariatan, Fakultas Hukum Universitas Brawijaya. 2014.

Suyud Margono. 2000. ADR (Alternatif Dispute Resolution) dan Arbitrase: Proses Perkembangan dan Aspek Hukum, Jakarta: Ghalia Indonesia.

Tim Penelitian Hukum. Peran Masyarakat Hukum Adat Dalam Penanggulangan Pembalakan Liar. Pusat Penelitian dan Pengembangan Sistem Hukum Nasional Badan Pembinaan Hukum Nasional Kementerian Hukum dan Hak Asasi Manusia RI. 2013. 